\title{
Distribution of bacteria and associated minerals in the gill chamber of the vent shrimp Rimicaris exoculata and related biogeochemical processes
}

\author{
Magali Zbinden ${ }^{1,2, *}$, Nadine Le Bris ${ }^{3}$, Françoise Gaill ${ }^{1}$, Philippe Compère ${ }^{2}$ \\ ${ }^{1}$ Systématique, Adaptation et Evolution, CNRS IRD MNHN UPMC, 7 Quai Saint Bernard, 75252 Paris cedex 05, France \\ ${ }^{2}$ Département des Sciences de la Vie, Institut de Zoologie, Université de Liège, 22 Quai Van Beneden, 4020 Liège, Belgium \\ ${ }^{3}$ Département Environnement Profond, IFREMER DRO, BP 70, 29280 Plouzané, France
}

\begin{abstract}
The shrimp Rimicaris exoculata dominates the megafauna of some Mid-Atlantic Ridge hydrothermal vent fields. This species harbours a rich bacterial epibiosis inside its gill chamber. At the 'Rainbow' vent site $\left(36^{\circ} 14.0^{\prime} \mathrm{N}\right)$, the epibionts are associated with iron oxide deposits. Investigation of both bacteria and minerals by scanning electron microscopy (SEM) and X-ray microanalysis (EDX) revealed 3 distinct compartments in the gill chamber: (1) the lower pre-branchial chamber, housing bacteria but devoid of minerals; (2) the 'true' branchial chamber, containing the gills and devoid of both bacteria and minerals; and (3) the upper pre-branchial chamber, housing the main ectosymbiotic bacterial community and associated mineral deposits. Our chemical and temperature data indicated that abiotic iron oxidation appears to be kinetically inhibited in the environment of the shrimps, which would explain the lack of iron oxide deposits in the first 2 compartments. We propose that iron oxidation is microbially promoted in the third area. The discrepancy between the spatial distribution of bacteria and minerals suggests that different bacterial metabolisms are involved in the first and third compartments. A possible explanation lies in the modification of physico-chemical conditions downstream of the gills that would reduce the oxygen content and favours the development of bacterial iron-oxidizers in this $\mathrm{Fe}^{\mathrm{II}}$-rich environment. A potential role of such iron-oxidizing symbionts in the shrimp diet is suggested. This would be unusual for hydrothermal ecosystems, in which most previously described symbioses rely on sulphide or methane as an energy source.
\end{abstract}

KEY WORDS: Crustacea $\cdot$ Deep-sea $\cdot$ Moulting cycle $\cdot$ Biomineralisation $\cdot$ Symbiosis $\cdot$ Iron oxidation Resale or republication not permitted without written consent of the publisher

\section{INTRODUCTION}

Caridean shrimps belonging to the Alvinocarididae family dominate the megafauna of many of the MAR (Mid-Atlantic Ridge) vent sites. Rimicaris exoculata (Williams \& Rona 1986) is particularly abundant, forming dense, motile swarms around the chimney walls (Segonzac 1992, Gebruk et al. 1993). R. exoculata carries a rich bacterial epibiosis that develops on different parts of the gill chamber (i.e. the inner side of the branchiostegites and the hypertrophied mouthparts) (Van Dover et al. 1988, Casanova et al. 1993, Gebruk et al. 1993, Segonzac et al. 1993). Molecular analyses of such bacteria, from Snake Pit (MAR) samples, suggested that the epibiont community consists of 1 single bacterial phylotype, belonging to the $\varepsilon$-Proteobacteria (Polz \& Cavanaugh 1995). They were hypothesised to acquire their metabolic energy from sulphide oxidation, but cultivation was unable to confirm this (Gebruk et al. 1993, Wirsen et al. 1993). Most of the studies on these epibionts have concerned their possible role in the shrimp diet. It was proposed that $R$. exoculata grazed either on bacteria living on the surface of the chimney (Van Dover et al. 1988), or on its epibiotic bacteria, regarded as ectosymbionts (Gebruk et al. 1993, 2000, Segonzac et al. 1993, Rieley et al. 1999) It has also been suggested that an autotrophic bacterial population living in the shrimp's gut might serve as a 
nutritional source (Pond et al. 1997, Polz et al. 1998, Zbinden \& Cambon-Bonavita 2003).

Previous studies have provided morphological descriptions of Rimicaris exoculata and its alvinocarididae relatives, and described the morphology of the epibionts (Casanova et al. 1993, Segonzac et al. 1993), but have neither focused on their spatial distribution, nor considered the development of the bacterial community in relation to the shrimp moulting stages. As with other arthropods, shrimps undergo cyclic moults, where the cuticle is regularly renewed. At ecdysis, when the entire old cuticle of the shrimp is shed, all the bacteria are shed with it, and a new cuticle covers the newly moulted shrimp. The abundance and distribution of the bacterial coverage seems to be related to the moulting cycle of the shrimp and to depend on the period of time elapsed since the last moult. Although nothing is known about the moulting cycle of $R$. exoculata and the duration of its moulting stages, in Crustacea the anecdysial period (taken as reference) is generally regarded as the longest stage of the moulting cycle, corresponding to a period of tegumental stability (for reviews see Vernet \& Charmantier-Daures 1994 and Compère et al. 2004).

Another important point that has not received special attention is the presence of mineral deposits within the gill chamber. Whereas at the TAG (trans-Atlantic geotraverse) site, the carapace area of some shrimps was described as dark, or even black, from the presence of sulphide particles associated with the bacteria by Gebruk et al. (1993), other authors (Wirsen et al. 1993) described filamentous bacteria on the inner cephalothorax surface associated either with rusty brown or black material. At the 'Rainbow' site, fairly abundant, rusty, mineral deposits surround the bacteria of the gill chamber of the shrimp. These rusty, bacteria-associated deposits were reported only recently in a paper that focused on their mineralogy (Gloter et al. 2004) and emphasised the very homogeneous and specific mineralogical composition of these iron oxide deposits, suggesting a direct role of bacteria in mineral formation.

Numerous authors have reported the occurrence of iron oxide deposits of putative microbial origin at deep-sea hydrothermal vents (e.g. Wirsen et al. 1993, Juniper et al. 1995, Fortin et al. 1998). More recent studies have highlighted the direct role of bacteria in the deposition of iron and suggested a major contribution of chemoautotrophic iron-oxidisers in this process (Emerson \& Moyer 2002, Kennedy et al. 2003). To date, however, the occurrence of such iron-oxidisers in association with animals has never been described. Our first aim was to undertake a detailed map of the distribution of both epibiotic bacterial and associated minerals within the whole gill chamber of Rimicaris exoculata including the mouthparts (i.e. the hypertrophied exopodites of the second maxilla, called scaphognathites, and the exopodites of the first maxillipeds) of shrimps in anecdysis. Our observations revealed 3 distinct areas on the gill chamber walls, which differed from each other not only in the abundance of bacteria and mineral deposits, but also in the nature of the minerals. Taking into consideration the water pathway through the gill chamber and the geochemical characteristics of the shrimp environment revealed by our in situ analysis and sampling data, this suggests the existence of three functionally different compartments. On this basis, we present further insights into the questions of the origin of these minerals, the spatial and functional relations between bacteria and minerals, and the biological role of the epibiosis.

\section{MATERIALS AND METHODS}

Shrimp collection and selection. Specimens of Rimicaris exoculata were collected during the French 'ATOS' cruise (June 2001), at the Rainbow vent site (36 $14.0^{\prime} \mathrm{N}$, Mid-Atlantic Ridge, $2300 \mathrm{~m}$ depth). Shrimps were collected with the suction sampler of the ROV 'Victor 6000' operating from the RV 'Atalante'. Immediately after retrieval, living specimens were dissected into body components (branchiostegites, scaphognathites, exopodites, gills, stomach and digestive tract). The samples were fixed either in a $2.5 \%$ glutaraldehyde/sodium cacodylate-buffered solution and later post-fixed in osmium tetroxide for morphological observations, or in a $2.5 \%$ glutaraldehyde/ seawater solution, without post-fixation, for X-ray microanalysis.

Shrimps in anecdysis were selected for observation according to the moult-staging method of Drach \& Tchernigovtzeff (1967), by examination of bristlebearing appendages (uropods) under the light microscope. The moulting stage was later confirmed by examination of the branchiostegite integument by light microscopy (LM) and transmission electron microscopy (TEM).

LM and TEM. Samples fixed for morphological observation were dehydrated in an ethanol and propylene oxide series and then embedded in an epoxy resin (Serlabo). Semi-thin and ultra-thin sections were obtained from a Reichert-Jung Ultramicrotome (Ultracut E) using a diamond knife. Semi-thin sections were stained with toluidine blue for observations by light microscopy (using a Nikon Optiphot-pol microscope and a Zeiss Opton photomicroscope). Ultra-thin sections were contrasted with uranium acetate and lead citrate, and observed on a Jeol (JEM 100-SX) transmission electron microscope operating at $80 \mathrm{kV}$. 
SEM and X-ray microanalysis. Before preparation, samples were observed with a stereomicroscope and photographed. Large samples were carefully dissected into small pieces that were dehydrated through an ethanol series, critical-point-dried and platinumcoated in a Balzers SCD-030 sputter-unit prior to observation in a scanning electron microscope (JEOL JSM-840A), operating at $20 \mathrm{kV}$.

Elemental energy-dispersive X-ray microanalyses (EDX) were performed either on the platinum-coated bulk samples prepared for SEM observation as previously described, or on carbon-coated semi-thin sections, cut at 1 to $2 \mu \mathrm{m}$ and mounted on carbon stubs. X-ray microanalyses and elemental mappings were performed in the SEM fitted with a Link Pentafet detector and a Link eXl-10 analyser.

Chemical analysis. Sulphide and ferrous iron were analysed in situ in the surroundings of shrimp swarms, using a submersible flow analyser mounted on the ROV 'Victor' (Le Bris et al. 2000). The analyser drew the sample from a deported inlet up to the colorimetric detection unit, located on the submersible. Analyses were performed within 5 min after sample collection at the ambient seawater temperature of $5^{\circ} \mathrm{C}$, thus preventing any oxidation of sulphide or ferrous iron with oxygen in the sample prior analysis. Probes for $\mathrm{pH}$ and temperature (MICREL, France) were combined with the analyser inlet (Le Bris et al. 2001). The sensors were positioned by the ROV manipulator to within a few centimetres of the shrimps, as confirmed by closeup video pictures. Only a coarse estimation of the $\mathrm{pH}$ $( \pm 0.5)$ could be obtained from in situ measurements, because of unusual baseline instabilities.

To complement the in situ analyses, water samples were collected in the vicinity of shrimps using the sequential fluid sampling system of the ROV and analysed on board ship for $\mathrm{pH}, \mathrm{H}_{2} \mathrm{~S}, \mathrm{O}_{2}$ and later onshore for total iron. A colorimetric flow-injection analysis method, adapted from Coale et al. (1991), was used for the determination of the total iron content in acidified subsamples. For the other parameters, standard laboratory analytical methods were used as described in Sarradin et al. (1998).

\section{RESULTS}

\section{Macroscopic observations of Rimicaris exoculata}

Macroscopic observations of Rimicaris exoculata revealed obvious morphological differences between individuals in anecdysis. The colour of the prebranchial pouch of the gill chamber varied from beige to dark orange-brown and was visible through the translucent branchiostegite carapace. Stereomicro- scopic observations showed that the coloration was related to the extent of the mineral deposits that covered the inner side of the branchiostegites, as well as the scaphognathite and exopodite surfaces that bear long bacteriophore setae. In beige individuals, the mineral deposits were scarce or absent. In dark orange-brown individuals, heavy mineral deposits appeared, located on all the cuticular surfaces in the upper pre-branchial chamber (above the exopodites), including both sides of the scaphognathites and the upper side of the exopodites. The mineral seemed to be much less abundant in the lower part of the prebranchial chamber and was almost completely absent from the gills and the walls of the 'true' posterior branchial chamber surrounding the gills. Observations of the inner side of the branchiostegites showed 3 well-delimited areas forming 3 distinct compartments (Figs. 1 \& 2a): (1) an antero-ventral area, which was relatively clear; (2) a posterior area, which always remained light beige; (3) an antero-dorsal area, which was intensely coloured.

\section{SEM and X-ray microanalysis}

\section{Morphology of bacteria}

Bacterial colonisation occurred on the shrimp mouthparts and the inner side of the branchiostegites in the form of a more or less thick mat of filaments (Figs. 3a-c \& 4a,b), whose density varied between areas

a

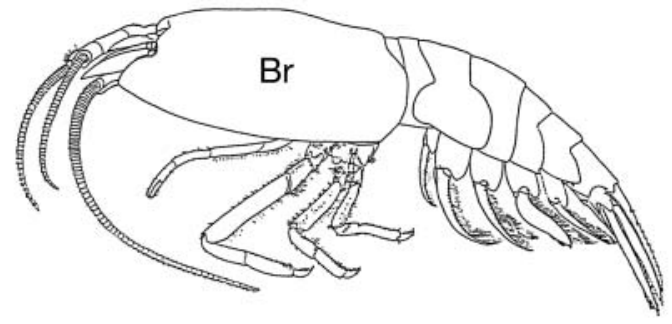

$\mathrm{b}$

Front

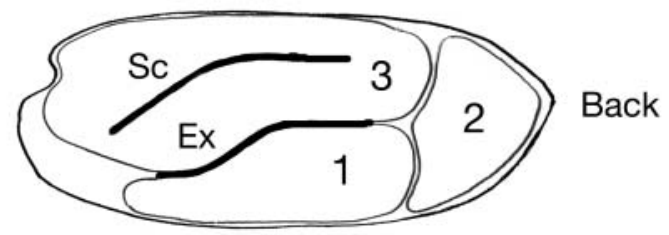

Fig. 1. Rimicaris exoculata. (a) Lateral view (from Williams \& Rona 1986); Br: branchiostegite. (b) Line-drawing of inner side of branchiostegite (right side), showing location of scaphognathite $(\mathrm{Sc})$, exopodite of 1st maxilliped (Ex) and delimiting 3 areas corresponding to 3 different compartments of the chamber: 1, antero-ventral area corresponding to lower pre-branchial chamber; 2, posterior area facing gills and corresponding to 'true' branchial chamber; 3, antero-dorsal area corresponding to upper pre-branchial chamber 

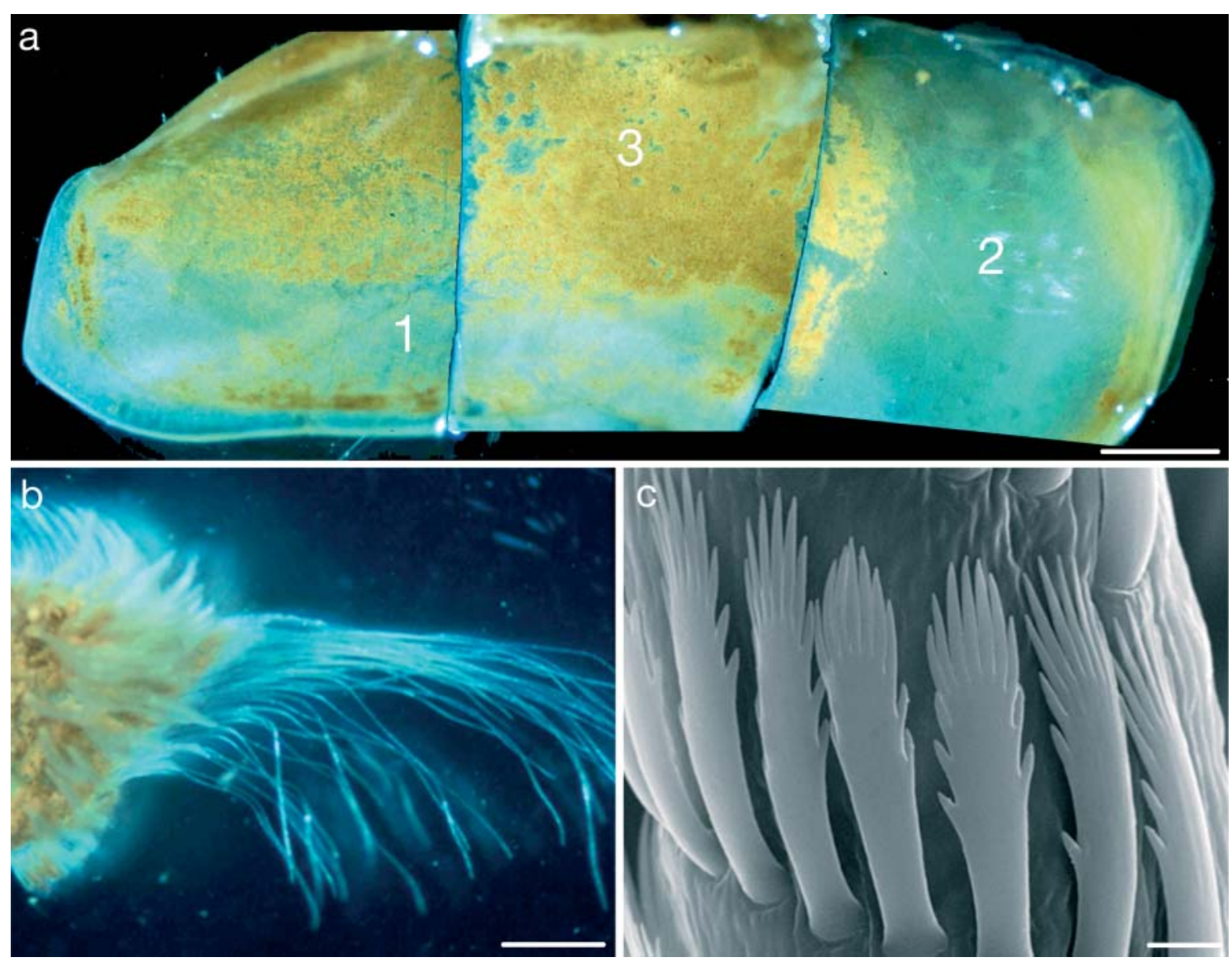

Fig. 2. Rimicaris exoculata. (a) Stereomicroscopic view of inner face of right side branchiostegite of a shrimp in anecdysis (comprising 3 photos), showing the 3 areas in Fig. 1(b) and medium amounts of rusty mineral deposits (iron oxides): 1, antero-ventral area characterised by few mineral deposits and bacteria; 2 , posterior area facing gills and devoid of mineral deposits and bacteria; 3, antero-dorsal area characterised by thick rusty crust of minerals associated with a heavy bacterial mat. (b) Dorsal stereomicroscopic view of right scaphognathite showing posterior end bearing long multidenticulate gill-cleaning setae. (c) SEM view of digitate scale setules of multidenticulate gill-cleaning setae of scaphognathite. Scale bars: $(\mathrm{a}, \mathrm{b})=2.5 \mathrm{~mm}$; $(\mathrm{c})=2 \mu \mathrm{m}$

(see subsection 'Distribution of bacteria and the mineral deposits'). There were 2 types of filaments of different diameter and length: thick filaments 2.5 to $3.0 \mu \mathrm{m}$ in diameter, and thin filaments 0.5 to $1.0 \mu \mathrm{m}$ (Fig. $4 \mathrm{~g}$ ). Length was more dificult to measure but, for both types, could range up to $250 \mu \mathrm{m}$. Individual rods were also observed $(0.5 \times 1.5 \mu \mathrm{m})$ at the base of the filamentous bacteria (Fig. 4f,h), as a mono- or bi-layer on the inner branchiostegite cuticle (Fig. 5) and on the bacteriophore setae of the mouthparts (not shown). In places where a monolayer occurred, it was either formed by prostrate or erect rod-shaped bacteria (Fig. 5d,e).

\section{Morphology of mineral deposits}

Mineral deposits observed macroscopically (Figs. 2a \& $3 a, e, f)$ mostly consisted of round-shaped particles of small size (200 to $1000 \mathrm{~nm}$ diameter) or as small both- roidal concretions that seemed to have an amorphous texture (Fig. 4e,f). In TEM sections (not illustrated), these particles displayed a multilayered inner structure, characteristic of bothroidal concretions. They were fairly coalescent, filling the spaces between the bases of the large filamentous bacteria (Fig. 4e), and were always associated with rod-shaped bacteria (Fig. 4f).

Rarer objects, mostly encountered on the lower face of the exopodites, were also observed as large black, angular particles with a crystalline appearance (Fig. 3e). These particles were only very occasionally observed in other areas of the gill chamber.

\section{Distribution of bacteria and mineral deposits}

Bacteria colonised almost all the available surfaces of the branchial chamber, with the notable exceptions of the gills and the inner side of the branchiostegites 

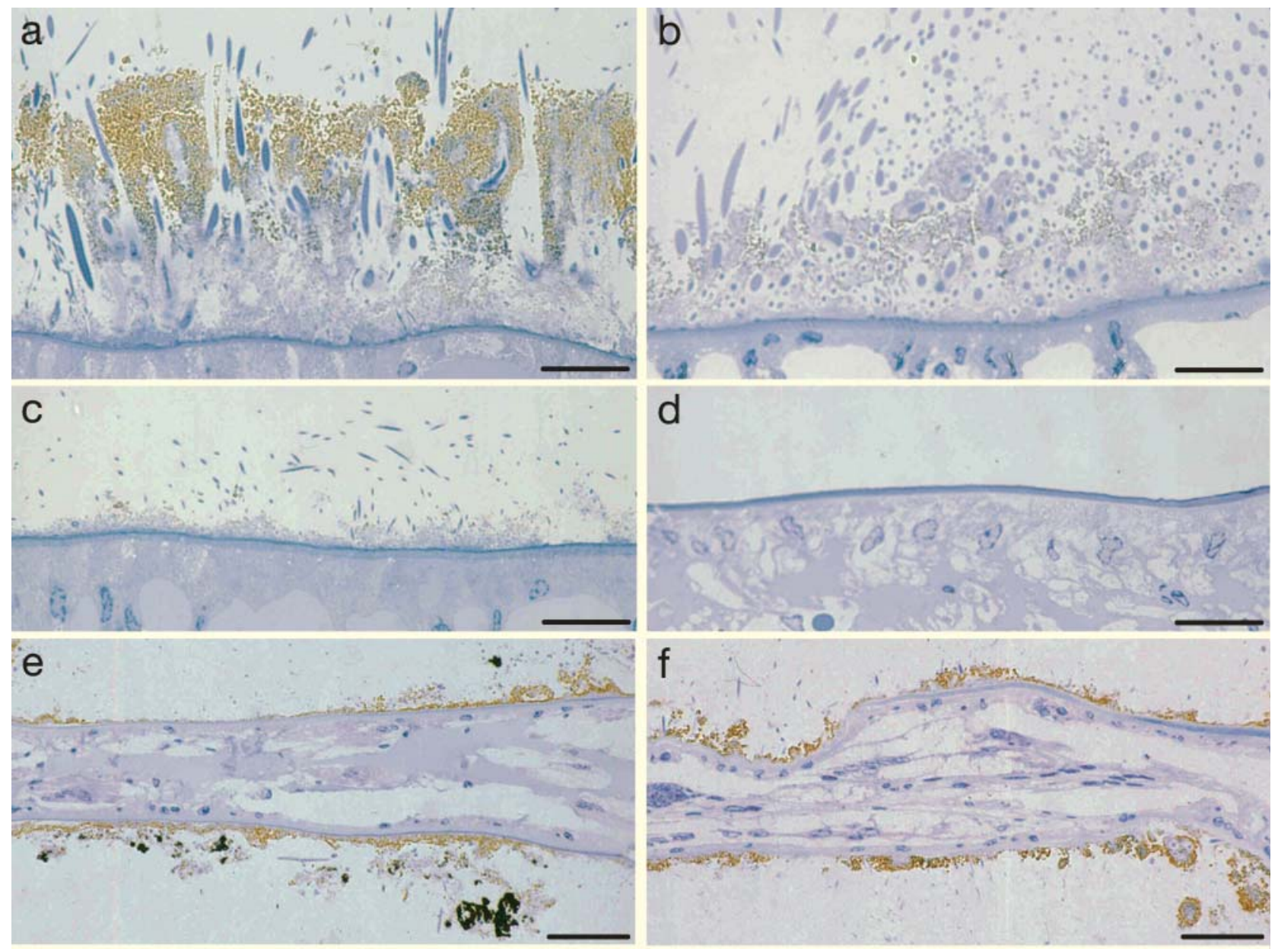

Fig. 3. Rimicaris exoculata. Semi-thin sections from 3 areas - inner branchiostegite integument, scaphognathite, and exopodite of the 1st maxilliped. $(\mathrm{a}, \mathrm{b})$ Antero-dorsal area of branchiostegite of (a) heavily and (b) weakly mineralised individual, with particulate orange-brown iron oxides.; (c) antero-ventral area of branchiostegite; (d) posterior area of the branchiostegite; (e) exopodite of first maxilliped of a heavily mineralised individual, showing occurrence of iron oxide (orange-brown) on both sides and of sulphides (black) mainly on ventral side; (f) scaphognathite of heavily mineralised individual, showing occurrence of iron oxides (orange-brown) on both sides. Scale bars: (a to d) $=50 \mu \mathrm{m} ;(\mathrm{e} \& \mathrm{f})=100 \mu \mathrm{m}$

facing the gills. SEM observations revealed the complete absence of both bacterial coverage and mineral deposits from these areas (Figs. 3d \& 5a). In the rest of the gill chamber, bacteria were present, sometimes in association with mineral deposits, but their distribution was not uniform. On the inner side of the branchiostegites, distribution of bacteria and minerals clearly defined the 3 distinct areas already observed macroscopically (Fig. 2a) and shown as a line-drawing (Fig. 1b).

The first area, occupying the antero-ventral part of the branchiostegites, was characterised by a thin bacterial coverage and the rare occurrence of mineral deposits (Fig. 3c). The density of bacteria was highest near the upper limit of this area and gradually decreased ventrally towards the epimeral fold of the branchiostegite (Fig. 5), where bacterial coverage was absent except in the groove close to the epimeral bor- der. As stated earlier, the dorsal (upper) limit of this area corresponded to the position of the hypertrophied exopodites of the first maxillipeds, which horizontally divide the pre-branchial chamber into an upper and lower compartment (see Fig. 1b).

In the second area, on the posterior part of the branchostegite facing the gills, the cuticle was bare, being totally devoided of bacteria and mineral deposits (Fig. 3d). This surface varied between individuals, being relatively rough, folded, or almost smooth (not illustrated).

The third area was the antero-dorsal region of the branchiostegites; this was characterised by a thick bacterial mat and varying amounts of mineral particles (orange-brown particles of iron oxide, see next subsection) in different individuals (cf. Fig. 3a with $3 b$ and Fig. $4 \mathrm{a}$ with $4 \mathrm{~b}$ ). The intensity of the rusty colouration 

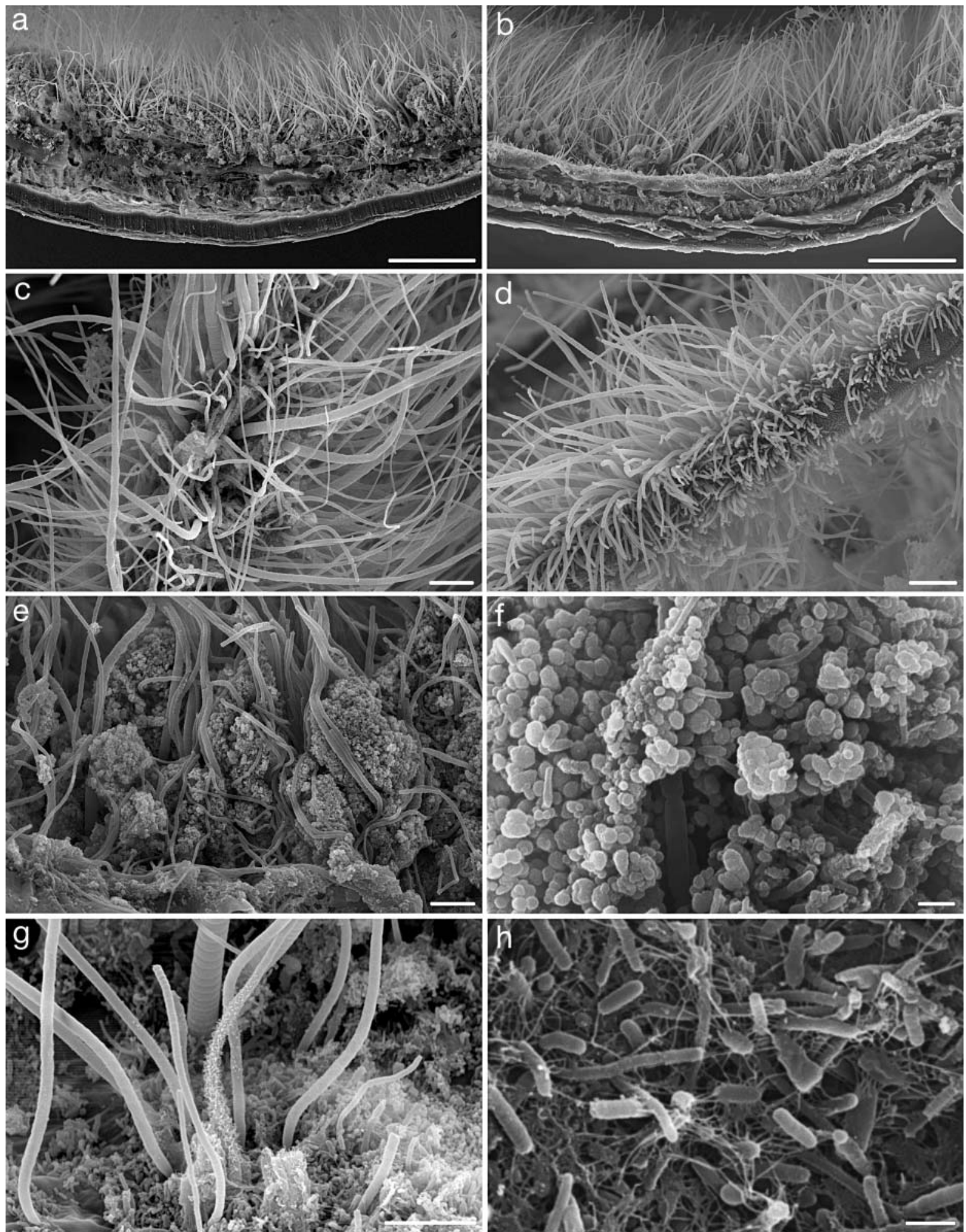

Fig. 4. Rimicaris exoculata. SEM micrographs of inner branchiostegite and bacteriophore setae of scaphognathite. (a, b) Vertical fracture in antero-dorsal area of branchiostegite showing bacterial coverage and mineral deposit in (a) heavily and (b) weakly mineralised individual; (c, d) bacterial mats and mineral deposits on bacteriophore setae of the scaphognathites in (c) heavily and (d) weakly mineralised individual; $(\mathrm{e}, \mathrm{f})$ details of mineral deposits in antero-dorsal area of branchiostegite; $(\mathrm{g}, \mathrm{h})$ details of bacterial diversity in antero-dorsal area of branchiostegite showing rod-shaped bacteria and thick and thin filaments. Scale bars: $(\mathrm{a}, \mathrm{b})=100 \mu \mathrm{m} ;(\mathrm{c}, \mathrm{d}, \mathrm{e}, \mathrm{g})=10 \mu \mathrm{m} ;(\mathrm{f}, \mathrm{h})=1 \mu \mathrm{m}$ 

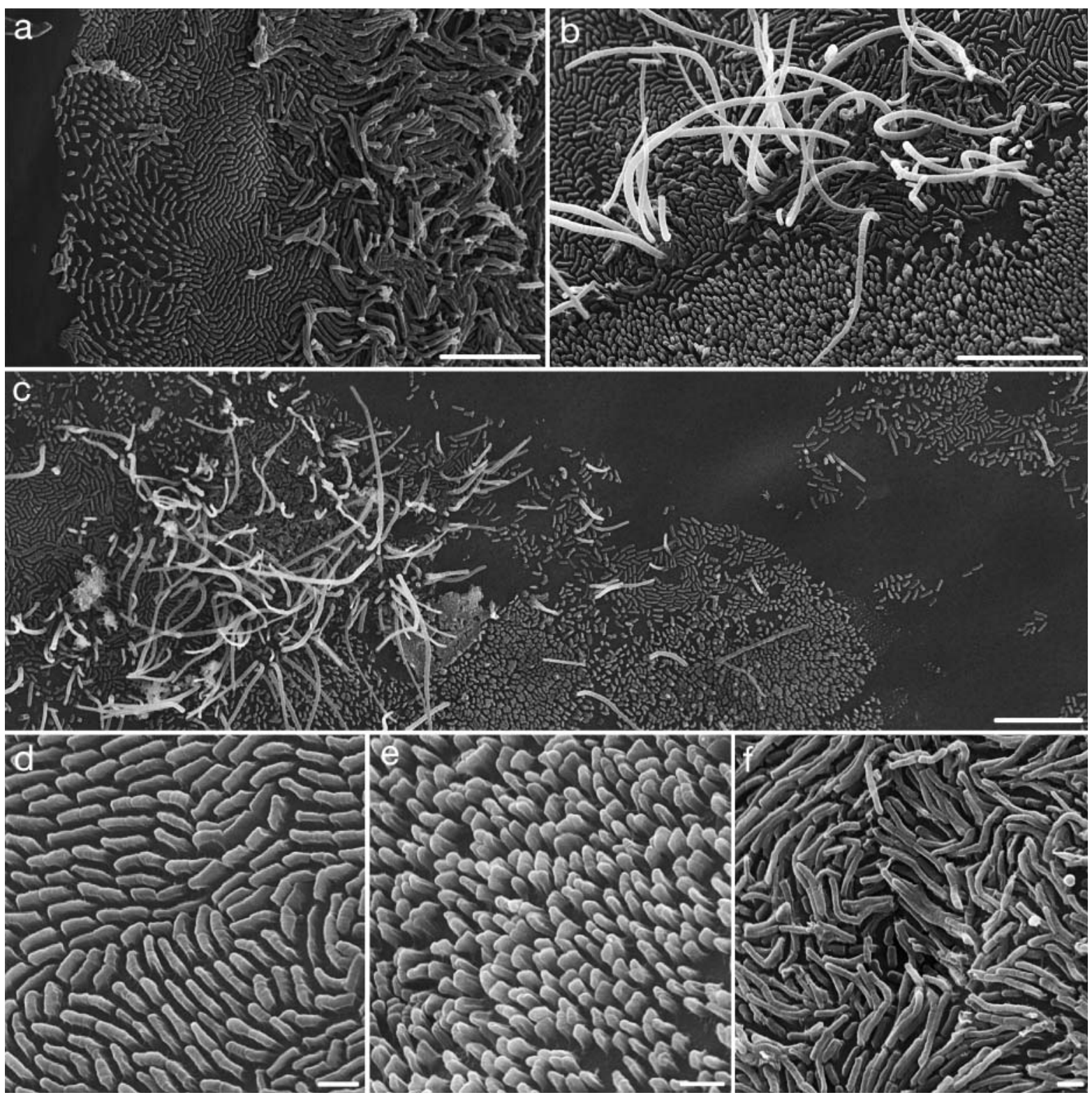

Fig. 5. Rimicaris exoculata. SEM micrographs of increasing bacterial coverage at boundary of the antero-dorsal and posterior areas of inner branchiostegite. (a) Emergence of monolayer of rod-shaped bacteria followed by bilayer of bacteria, the latter comparising short prostrate filaments. (b) Detail of short erect filaments emerging from bilayer of prostrate filaments and surrounded by monolayers of prostrate and erect rod-shaped bacteria. (c) General view of boundary area showing free surface, monolayers, and erect short filaments. (d-f) Details of bacterial morphotypes: monolayers of prostrate (d) and erect (e) rod-shaped bacteria, and bi-layer of short prostrate filaments (f). Scale bars: $(a-c)=10 \mu m_{i}(d-f)=1 \mu \mathrm{m}$

observed macroscopically (Fig. 2a) was directly related to the thickness of the mineral crust; abundance of bacteria and thickness of bacterial coverage varied inversely with thickness of the mineral crust. Abundant long bacterial filaments were encountered in beige individuals with few mineral deposits on the gill chamber walls and mouthparts (Figs. 3b \& 4b); in these individuals, thickness of the bacterial coverage reached a maximum of $150 \mu \mathrm{m}$. In contrast, in heavily miner- alised individuals, in which the mineral crust reached a maximum thickness of $60 \mu \mathrm{m}$, filamentous bacteria emerging from the mineral crust were rarer (Figs. 3a $\& 4 \mathrm{a})$, and rod-shaped bacteria occurred between the mineral particles.

At the boundaries between the areas of thick bacterial mats and the zones that remained free (i.e. between the antero-dorsal area and the posterior or anteroventral areas), bacterial coverage was progressive, 
showing gradual steps of colonisation. In direct contact with the free zones, there first appeared a monolayer of isolated rod-shaped bacteria ( 0.5 to $1 \mu \mathrm{m}$ in length) (Fig. 5a to c) that either adopted a prostrate (Fig. 5b,d) or erect (Fig. 5b,e) position. Then followed a bilayer (Fig. 5a,f) formed by short prostrate filaments (up to $2 \mu \mathrm{m}$ ) of 2 or 3 cells that seemed to be in division. In some places, thin erect filaments (Fig. 5b,c) arose from the bilayer through growth of the prostrate filaments. They appeared multicellular, but remained relatively short (from 2.5 to $20 \mu \mathrm{m}$ ). The spatial density of these thin erect filaments rapidly increased towards the zones of thick bacterial mats, which included thick erect filaments in addition to thin filaments and isolated bacteria (Fig. 4e,g). On the outer face of the branchiostegites, bacteria were few, with only small mono-layered patches of rods and small mats of short filaments near the base of the sensory setae (not shown).

Entirely enclosed in the upper pre-branchial chamber, the scaphognathites showed on both sides the same bacterial coverage and mineral deposits (Fig. 3f) as the antero-dorsal area of the branchiostegites. Bacteria (rods and filaments) densely covered the cuticular surface as well as the long bacteriophore setae (Fig. 4c,d). As on the branchiostegites, the density of the mineral deposits and the importance of the bacterial coverage on the scaphognathites varied widely between individuals, but presented the same features on both sides.

Separating the upper and lower compartments of the pre-branchial chamber, the expodites showed on both sides a bacterial coverage roughly similar to that of the scaphognathites. On the dorsal side, the mineral deposit was also similar to that on the scaphognathites, and mainly consisted of iron oxide (see next subsection); it was often less marked on the ventral side which, in contrast, displayed a number of black angular particles (Fig. 3e).

\section{Element composition of particles (Fig. 6)}

X-ray spectra (Fig. 6j) and maps (Fig. 6b,c,d,e) of the orange-brown deposit particles revealed the dominance of iron (Fe) (major peaks $\mathrm{K} \alpha$ at $6.400 \mathrm{keV}$ and $\mathrm{K} \beta$ at $7.059 \mathrm{keV}$ ), but also the occurrence of calcium (Ca) (minor peaks $\mathrm{K} \alpha$ at $3.690 \mathrm{keV}$ and $\mathrm{K} \beta$ at $4.012 \mathrm{keV}$ ) and traces of silica (Si) (Ko at $1.740 \mathrm{keV})$, phosphorus (P) $(\mathrm{K} \alpha$ at $2.013 \mathrm{keV})$ and sulphur (S) (Ko at $2.307 \mathrm{keV})$. The element maps also show that the distribution of these elements within the mineral crust was uniform. The mineralogy of the amorphous particles forming the deposit was investigated in a previous study by means of TEM and electron energy loss spectroscopy (EELS), and it was concluded that these particles consisted of iron oxyhydroxides in the form of ferrihydrite (Gloter et al. 2004).
X-ray spectra (Fig. 6k) and maps (Fig. 6g,h,i) of the black mineral particles on the lower side of the exopodites revealed 4 elements only: S (major K $\alpha$ peak at $2.307 \mathrm{keV}), \mathrm{Fe}(\mathrm{K} \alpha$ at $6.400 \mathrm{keV}$ and $\mathrm{K} \beta$ at $7.059 \mathrm{keV}), \mathrm{Cu}(\mathrm{K} \alpha$ at $8.041 \mathrm{keV}$ and $\mathrm{K} \beta$ at $8.907 \mathrm{keV})$ and/or $\mathrm{Zn}(\mathrm{K} \alpha$ at $8.681 \mathrm{keV}$ and $\mathrm{K} \beta$ at $9.572 \mathrm{keV})$, according to the particles analysed. These particles thus appeared to be composed of zinc/iron and copper/iron sulphides.

\section{Chemical and thermal environment of Rimicaris exoculata}

In situ measurements of temperature, $\mathrm{pH}$, ferrous iron and sulphide concentrations in the shrimp's environment reflected mixing of the vent fluid with seawater, with a moderate contribution of the fluid (Table 1). The mean temperature was several degrees above that of ambient seawater $\left(2^{\circ} \mathrm{C}\right)$. The in situ $\mathrm{pH}$ ranged from that of the alkaline seawater $(\mathrm{pH} \sim 8)$ to a near-neutral level. The most important feature was the high level of ferrous iron in this environment (more than $100 \mu \mathrm{M}$ ). In comparison, sulphide was only slightly enriched $(<3 \mu \mathrm{M})$. Discrete samples were consistent with the in situ ranges, also displaying approximately neutral $\mathrm{pH}$ and iron enrichment (Table 2). Their sulphide range was even slightly below the in situ range, probably due

Table 1. In situ temperature, $\mathrm{pH}$, ferrous iron $\left(\mathrm{Fe}^{\mathrm{II}}\right)$ and sulphide $\left(\mathrm{S}^{-\mathrm{II}}\right)$ concentrations in environment of Rimicaris exoculata swarms. Values are means $\pm \mathrm{SD}$ and (ranges)

\begin{tabular}{|lccc|}
\hline$T\left({ }^{\circ} \mathrm{C}\right)$ & $\mathrm{pH}$ & $\mathrm{Fe}^{\mathrm{II}}(\mu \mathrm{M})$ & $\mathrm{S}^{-\mathrm{II}}(\mu \mathrm{M})$ \\
\hline $8.7 \pm 2.3$ & & $134 \pm 60$ & $1.6 \pm 1.4$ \\
$(3.8-14.7)$ & $(7-8)$ & $(56-265)$ & $(0.4-6.3)$ \\
$(\mathrm{n}=327)$ & $(\mathrm{n}=327)$ & $(\mathrm{n}=24)$ & $(\mathrm{n}=17)$ \\
\hline
\end{tabular}

Table 2. $\mathrm{pH}$ (at $\left.25^{\circ} \mathrm{C}, 1 \mathrm{~atm}\right), \mathrm{O}_{2}$, total sulphide ( $\mathrm{S}^{-\mathrm{II}}$ ) and total iron $\left(\mathrm{Fe}^{\mathrm{II}}+\mathrm{Fe}^{\mathrm{III}}\right)$ concentrations in discrete samples of ambient seawater and of fluid in vicinity of Rimicaris exoculata swarms, and at outlet of a black smoker. nd: no data

\begin{tabular}{|c|c|c|c|c|}
\hline Sample & $\mathrm{pH}$ & $\begin{array}{c}\mathrm{O}_{2} \\
\mu \mathrm{M}\end{array}$ & $\begin{array}{l}S^{-I I} \\
\mu M\end{array}$ & $\begin{array}{c}\mathrm{Fe}^{\mathrm{II}}+\mathrm{Fe}^{\mathrm{III}} \\
\mu \mathrm{M}\end{array}$ \\
\hline Ambient seawater & $\begin{array}{c}7.8 \\
(n=2)\end{array}$ & $\begin{array}{c}242 \\
(\mathrm{n}=2)\end{array}$ & $\begin{array}{l}<0.1 \\
(\mathrm{n}=2)\end{array}$ & $\begin{array}{l}<0.5 \\
(\mathrm{n}=2)\end{array}$ \\
\hline Shrimp swarms & $\begin{array}{c}7.0 \\
6.8-7.3 \\
(n=4)\end{array}$ & $\begin{array}{c}166 \\
63-236 \\
(n=3)\end{array}$ & $\begin{array}{c}<- \\
<0.1-2.7 \\
(\mathrm{n}=4)\end{array}$ & $\begin{array}{c}73 \\
45-101 \\
(n=4)\end{array}$ \\
\hline Smoker output & $\begin{array}{c}5.6 \\
5.3-6.1 \\
(\mathrm{n}=3)\end{array}$ & $\begin{array}{c}12.4 \\
<0.1-37 \\
(\mathrm{n}=3)\end{array}$ & nd & $\begin{array}{c}5197 \\
1620-8425 \\
(\mathrm{n}=3)\end{array}$ \\
\hline
\end{tabular}



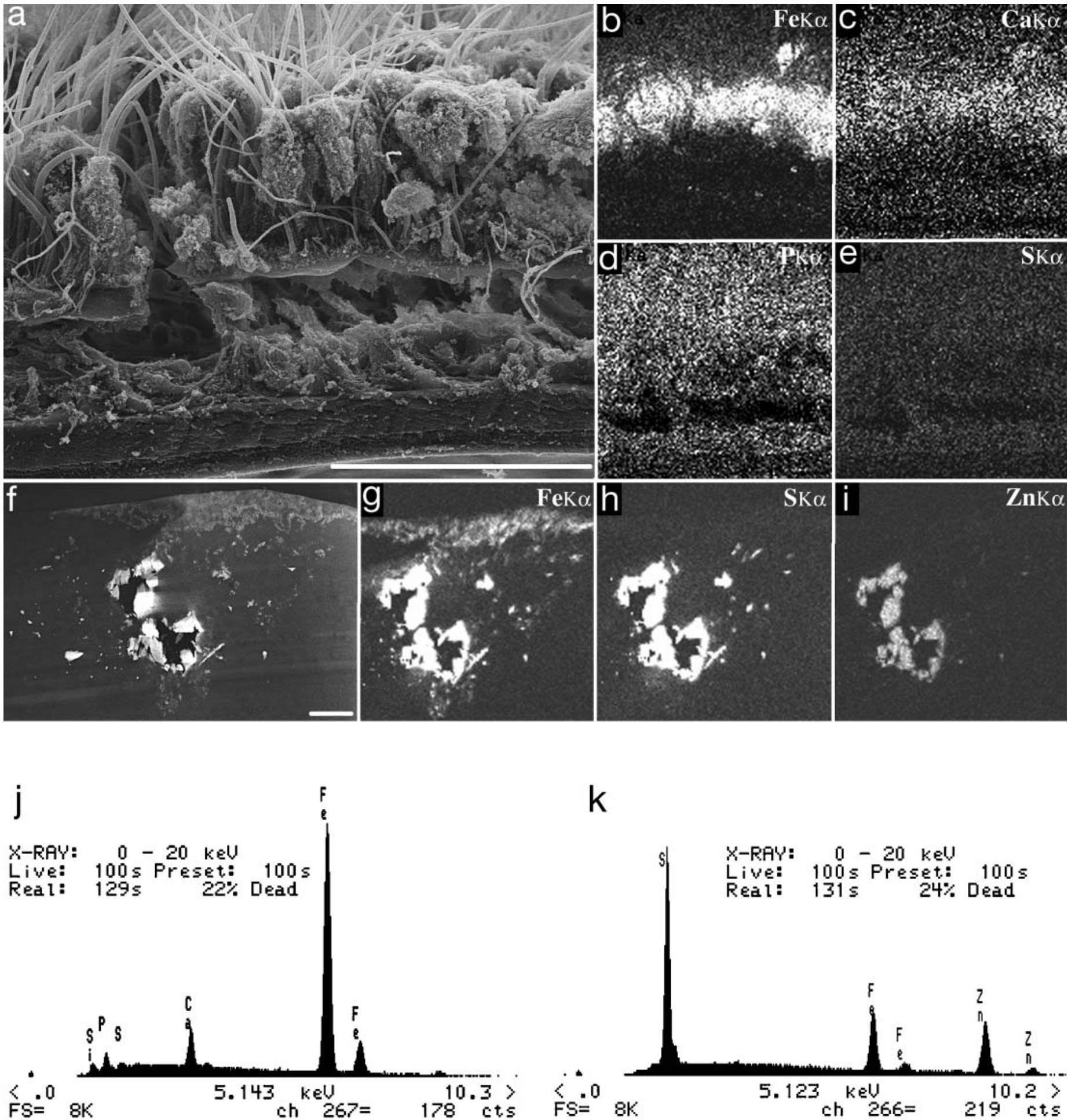

Fig. 6. Rimicaris exoculata. Element X-ray microanalyses and maps of mineral deposits in gill chamber (a) SEM image: (b)-(e); and X-ray maps of vertical fracture in antero-dorsal area of inner branchiostegite from heavily mineralised individual, showing (b) distribution of iron associated with (c) calcium and (d) phosphorus. (e) Sulphur is totally absent. (f)-(i) Semi-thin sections of resin-embedded exopodite of first maxilliped showing mineral deposits adhering to its lower face, including large black sulphide particle. (f) SEM image. (g) Elemental maps of iron, (h) sulphur and (i) zinc; largest particle is black zinc/iron sulphide particle surrounded by small iron sulphide particles. In contact with the cuticle is a thin crust of small iron-oxide particles. (j) X-ray spectrum of mineral deposit on the face of branchiostegite (as in a) showing major Fe peaks and minor peaks of $\mathrm{Ca}, \mathrm{Si}, \mathrm{P}$ and $\mathrm{S}$. (k) X-ray spectrum of the black sulphide particle (f), showing $\mathrm{S}, \mathrm{Fe}$ and $\mathrm{Zn}$. Scale bars: 
to sulphide oxidation in the sampling vials during collection. It is interesting to note that the total iron (i.e. $\mathrm{Fe}^{\mathrm{II}}+\mathrm{Fe}^{\mathrm{III}}$ ) in the samples was of the same order of magnitude as the average ferrous iron content determined in situ, indicating that ferric iron did not represent a substantial fraction of iron in the fluid phase surrounding shrimp swarms. Even though the oxygen content in samples could have been underestimated, since oxygen uptake can occur in the sample bottles during retrieval to the surface, its level in these samples was still about two-thirds of the atmospheric-saturation level for seawater (at $25^{\circ} \mathrm{C}$ ). The oxygen content in the environment of the shrimps thus remained quite high, in comparison to the largely oxygen-depleted conditions at the smoker outlets (Table 2). All these results indicated chemical conditions in the immediate surroundings of the shrimp as being intermediate between ambient seawater conditions and the more acidic and reduced fluid at the black smoker outlets. They reflected a metastable state in which reduced species ( $\mathrm{Fe}^{\mathrm{II}}$, sulphide) coexisted with oxidized species (oxygen), similar to the situation described for other vent habitats (Johnson et al. 1988). The large predominance of iron over sulphide in the mixing zone was however atypical in comparison to the other vent habitats studied (Johnson et al. 1988, Luther et al. 2001, Le Bris et al. 2003).

\section{DISCUSSION}

\section{Spatial distribution of the bacteria/mineral association in the branchial chamber}

According to the literature on water flow in the branchial chamber of Rimicaris exoculata (Casanova et al. 1993), the water current generated by the beating of the scaphognathites runs through the gill chamber, entering ventrally and exiting anteriorly. The flow thus passes from the lower pre-branchial chamber (first compartment), to the gills (second compartment), and then through the upper prebranchial chamber containing the epibiont community (third compartment). Analysis of the mineral distribution in the gill chamber revealed 2 important factors: (1) Metal sulphide particles occur almost solely on the lower face of the exopodites and on the surface of the antero-ventral area of the branchiostegites. These sulphide particles have a structure and composition typical of high-temperature plume particles (James \& Elderfield 1996), indicating that the lower pre-branchial compartment may serve as a barrier against ambient particles. The long setae at the lower side of the exopodites would act as a filter to prevent penetration of particles and their accumula- tion in the gill chamber. Our results clearly confirm that water enters the gill chamber along the ventral side and flows out along the dorsal side. (2) Iron oxides are abundant in the upper pre-branchial compartment, whereas they are almost totally absent from the lower pre-branchial and posterior branchial compartments. The spatial variability in the mineraldeposit distribution is clearly related to the direction of the water flow, the upper pre-branchial compartment with the epibionts being located downstream of the gills in the water flow.

The absence of bacteria from the posterior area of the branchiostegites facing the gills, as well as from the gills themselves, is surprising in this environment, in which nearly all available surfaces are colonised by the epibionts. This absence of bacteria probably results from movement of the scaphognathites, which may act as gill-cleaners. They bear long multidenticulate setae with digitate scale setules at their posterior end (Fig. 2c). Such scaphognathites features are reported to comprise one of the passive gill-cleaning mechanisms in crustaceans, as described for caridean atyid shrimps by Suzuki \& McLay (1998) and the mudlobster Thalassina anomalia by Batang \& Suzuki (1999). The functional importance of the gills as exchange surfaces in the shrimp's metabolism requires them to remain free of any microorganism and deposit, which would increase the diffusion distance between the haemolymph and the external medium.

The absence of bacteria from the outer face of the branchiostegites (except for small depressions around the bases of the setae) is also puzzling. Attempts to submerge the branchiostegites in aqueous fixatives have shown that the outer face is highly hydrophobic. The outer membrane of the bacteria is a lipid bilayer, containing proteins and sugars that give it a hydrophilic character. This could explain why bacteria are not able to colonise the hydrophobic outer face of the branchiostegites. The same could be true for the whole cephalothoracic shield and the abdominal tergites, which macroscopically always appear smooth and free of encrusting organisms.

\section{Biogeochemical processes}

Metazoan-associated bacteria have been reported to lead to the formation of iron minerals at hydrothermal vents (Zbinden et al. 2001, 2003, Lechaire et al. 2002), but until now never to the formation of iron oxides. The precipitation and accumulation of iron oxides in association with bacterial cells is common in aqueous environments, where high concentrations of $\mathrm{Fe}^{\mathrm{III}}$ are produced by the oxidation of the reduced form $\mathrm{Fe}^{\mathrm{II}}$ (Juniper \& Tebo 1995, Ferris et al. 2000). The formation 
of epicellular iron oxides by bacteria can occur either passively or actively. In the first case, bacteria provide nucleation sites for iron oxides through the electrostatic binding of dissolved ferric species to the anionic structural polymers of the cellwall. These bacteriaassociated iron oxides have a chemical composition similar to those produced abiotically in solution (Konhauser 1998). Alternatively, bacteria can induce ferric oxide precipitation as a result of their metabolism. This can be done indirectly, by local alteration of the $\mathrm{pH}$ and redox conditions around the cell (Konhauser 1998), or by production of extracellular organic polymers that bind ferric iron and promote oxide nucleation and growth; or directly, by oxidation of $\mathrm{Fe}^{\mathrm{II}}$ as an electron donor in their metabolism (Emerson \& Moyer 1997, 2002, Straub et al. 2001, Neubauer et al. 2002).

The spatial heterogeneity of the mineral/bacteria association observed in this study indicates that precipitation is not just a passive nucleation process. Furthermore, the uncommon mixed-valence ferrihydrite mineralogy described for iron oxide (Gloter et al. 2004) suggests bacterial iron oxidation (Edwards et al. 2003). A direct role of the epibionts in the formation of the deposits is thus strongly suggested.

In oxic environments, spontaneous ferrous iron oxidation is extremely rapid at ambient temperature $\left(25^{\circ} \mathrm{C}\right)$ and neutral pH (Emerson \& Moyer 1997, Neubauer et al. 2002). Under these conditions, Fe-oxidizing bacteria may find it difficult to compete with the abiotic process. In the present study, however, the temperature was low and oxygen was reduced to about two-thirds of its level in air-saturated seawater. Abiotic oxidation is much slower under such conditions. As calculated from the kinetic study of Millero et al. (1987), the Fe ${ }^{\mathrm{II}}$ half-life would be about $35 \mathrm{~h}$ in a shrimp environment, whereas it is only of a few minutes in air-saturated seawater at $25^{\circ} \mathrm{C}$. Our in situ analyses confirmed that iron mostly remains in its metastable reduced form in the surroundings of the shrimp. The absence of iron oxides from the first chamber is consistent with this slow abiotic oxidation rate and denotes the absence of a nucleation effect at the bacterial cell surface. In contrast, the abundance of iron oxides in the third chamber indicates that iron oxidation is promoted in this microenvironment.

In the upper pre-chamber, i.e. downstream of the gills in the water flow, a $\mathrm{pH}$ reduction, a $\mathrm{CO}_{2}$ increase and an $\mathrm{O}_{2}$ decrease can be expected as a result of shrimp respiration. According to Millero et al. (1987) and King (1998), all these changes should lead to a decrease in the abiotic oxidation rate. This further supports the idea of a microbially-mediated oxidation, at least for the first mineral deposition stage. Ironoxidizing microorganisms have been shown to require micro-aerophilic conditions for growth at ambient temperature (Emerson \& Moyer 1997, Neubauer et al. 2002). It is not known whether such a low oxygen requirement is also valid at low temperatures, where competion with the abiotic process is not so critical, but a possible explanation to the observed dissimilarity between the 2 chambers would be the presence of a gradient in oxygen content in the shrimp branchial cavity.

It has been previously reported, for the Snake Pit site, that the bacteria in the whole gill chamber of the shrimp belong to the same phylotype (Polz \& Cavanaugh 1995). If this is also the case for shrimp from our study site, it would appear that the bacteria of the pre-branchial chamber resort to a different metabolism because of local conditions. As described for Acidothiobacillus ferrooxidans (Rawlings \& Kusano 1994), some bacteria are able to obtain their energy through the oxidation of either ferrous iron or reduced inorganic sulphur compounds, depending on the availability of these elements in the surrounding fluid. However, without further investigations, it is hazardous to extrapolate the conclusion drawn for shrimp epibionts at the Snake Pit vent site to those at the Rainbow site. The Rainbow hydrothermal fluid chemistry is indeed highly different from that at the Snake Pit, especially with respect to its exceptionally high iron enrichment and quite low sulphide content (Charlou et al. 2002, Douville et al. 2002). It is also conceivable that a different and more diversified microflora inhabits the gill chamber of Rimicaris exoculata at the Rainbow site.

As discussed in Emerson \& Moyer (1997) and referenced herein, ferrous iron oxidation under neutral and microaerophilic conditions can provide enough energy to drive chemoautotrophic $\mathrm{CO}_{2}$ fixation. The energy budget of iron oxidation greatly depends on environmental conditions, and especially pH (Straub et al. 2001, Emerson \& Moyer 2002). Using the standard Gibbs free-energies listed in Buffle \& De Vitre (1994), we obtained a first estimation of the energy available from the different redox pathways. At $\mathrm{pH} 7$ and under standard conditions, the energy available from the oxidation of ferrous iron to amorphous iron oxyhydroxide is $228 \mathrm{~kJ} \mathrm{~mol}^{-1}$ (while it is only $44 \mathrm{~kJ} \mathrm{~mol}^{-1}$ at $\mathrm{pH} 2$ for ferric iron in dissolved form). This energy budget would be even larger if a more crystalline phase were formed. In comparison, oxidation of sulphide to sulphate would provide $797 \mathrm{~kJ} \mathrm{~mol}^{-1}$ and oxidation of sulphide to elemental sulphur only $209 \mathrm{~kJ} \mathrm{~mol}^{-1}$. As iron is on average 85-fold higher than sulphide in the environment of the Rainbow shrimp swarms, the energy available for chemoautotrophic primary production in these conditions would be 25 to 100 higher with iron as electron donor than with sulphide. 


\section{Potential biological role of epibiosis}

The epibiotic bacteria appear to take advantage of a specific microenvironment in the gill chamber, where conditions are optimal for their growth; this may not be the case on the mineral surfaces exposed to the outer medium. Some direct or indirect benefits for the shrimp are not necessarily involved, but several hypotheses have been raised and are discussed below.

\section{Detoxification}

In comparison to ambient seawater, the Rainbow hydrothermal fluid is enriched in toxic heavy metals and radioactive elements (Douville et al. 2002). These compounds adsorb onto iron oxides (Ferris et al. 2002), and their elimination from the dissolved phase results in the lowering of their capacity to pass through biological membranes and, hence, reduces their toxicity. In the present study, the absence of iron oxides from the branchial chamber or the lower pre-branchial chamber upstream of the gills does not support the idea of a 'detoxification mechanism' with respect to the respiratory organs. If detoxification occurs through adsorption onto the iron oxide particles, it would be only significant in the last chamber, i.e. in the upper prebranchial chamber situated downstream of the gills.

\section{Shrimp diet}

One hypothesis concerning the role of the epibionts suggests that Rimicaris exoculata gains most of its carbon from the epibiotic bacteria living within its carapace (Rieley et al. 1999), by scraping and grazing on them (Gebruk et al. 1993). Our observations on numerous specimens however did not reveal scraped areas on the walls of the pre-branchial chamber (inner side of the branchiostegites) nor on the mouthparts. The bacterial biofilm never seems damaged mechanically by the appendages (with the exception of its complete removal from the gills and branchial chamber walls by the gill-cleaning setae of the scaphognathites). It is thus unlikely that the shrimps graze on their own bacteria. In order for shrimp to obtain carbon from their epibionts, 3 processes are suggested. (1) The shrimps could consume their exuviae (i.e the old moulted cuticle) and thus ingest the epibionts. Our observations of gut contents did reveal the presence of cuticle fragments (data not shown) in a shrimp in late anecdysis, which had heavy mineral oxide deposits in its prebranchial chamber. Maintainance of shrimps in a pressure vessel (Shillito et al. 2001) for 24 or $30 \mathrm{~h}$ has shown that digestive transit in Rimicaris exoculata is fairly rapid (guts are completely empty of minerals and organic residues after this time; M. Zbinden unpubl.). It is thus unlikely that the individual we observed had ingested its own exuvium, but rather that the cuticle fragments originated from the exuviae of other shrimp. Questions that arise are: are there sufficient bacteria on the exuviae and are moults frequent enough to feed the shrimp, taking into account the metabolic cost of moulting and the fact that bacterial coverage increasingly regresses in shrimps approaching their next moult?

(2) Trans-epidermal transfer of dissolved organic matter from the epibiotic bacteria could occur through the branchiostegite cuticle. This hypothesis has already been suggested for the filamentous bacteria present on the mouthparts of this shrimp (Casanova et al. 1993). Although, Gebruk et al. (2000) did not agree with this hypothesis (on the basis of studies on other Crustacea which showed the active transport of dissolved organic matter to be unlikely), the hypothesis is supported by recent TEM observations of the epithelium lining the inner face of the branchiostegites of Rimicaris exoculata. The epidermal cells exhibit apical membrane infoldings (Martinez 2001) and are rich in mitochondria, suggesting epidermal transport activity (J. B. Braquenier \& P. Compère unpubl. data).

(3) Absorption of hydrolysates resulting from bacterial activity in the gut has also been suggested to occur through the hindgut cuticle of the deposit-feeding shrimp Nyotrypaea californiensis (Lau et al. 2002). On the basis of the presence of an intact bacterial microflora in Rimicaris exoculata gut, a trans-epithelial transfer through the gut endoderm has also been suggested (Zbinden \& Cambon-Bonavita 2003), but this remains to be demonstrated.

If such trans-epidermal nutrition does occur at the upper pre-branchial chamber level then the Rimicaris exoculata ectosymbiosis would appear to be unique in comparison to other vent symbioses, not only in regard to the nature of the host (such symbioses have never been reported for other crustaceans), but also in regard to its iron oxidative microbial metabolism, since most symbioses studied so far rely only on sulphide or methane oxidation (Nelson \& Fisher 1995).

On the basis of their morphological resemblance to Thiotrix spp., these epibionts were previously inferred to be sulphur-oxidisers (Gebruk et al. 1993), but until now, attempts to cultivate these bacteria have remained unsuccessful. Chemoautotrophic growth activity of the filamentous bacteria from the inner cephalothorax surface has nevertheless been demonstrated (Wirsen et al. 1993), with higher values measured in the rusty brown bacterial films than in the more reduced blackish films. Furthermore, $\mathrm{CO}_{2}$ incorporation was detected on scrapings of shrimps cara- 
paces and scaphognathites, but no significant increase in fixation was observed in the presence of reduced sulphur compounds (Polz et al. 1998).

As previously discussed (Emerson \& Moyer 1997, 2002), iron redox gradients in advective systems can constitute ideal habitats for aerobic neutrophilic iron oxidisers. Our in situ and discrete-sample chemical analyses indicate that the environment of shrimp swarms meets these requirements. The shrimp's gill chamber provides a large surface for microbial growth with a controlled and constantly renewed access to reduced iron and oxygen. Iron oxidation could constitute a significant energetic option in a medium where ferrous iron is unusually enriched whereas sulphide (a main electron donor at most Mid-Atlantic Ridge or East Pacific Rise vent sites) is low.

Among the sites explored to date, the Rainbow hydrothermal fluid is exceptionally rich in iron (24 mmol kg-1; Douville et al. 2002), and is considered an atypical hydrothermal fluid in this respect (Allen \& Seyfried 2003). Its high iron content gave us unique opportunity of demonstrating the possibility of diverse metabolic pathways of the microbial epibiosis associated with Rimicaris exoculata. However, the ironoxidiser epibionts of $R$. exoculata may not be restricted to this site. Rusty minerals associated with $R$. exoculata epibionts have also been described from other MidAtlantic sites (Wirsen et al. 1993), and deserve further investigation. At the TAG site, particularly, the iron content of its hydrothermal fluid, although not so dominant over sulphide, reaches values of $5.5 \mathrm{mmol} \mathrm{kg}{ }^{-1}$. This is substantially higher than that of the other MAR sites, except for Rainbow. A newly discovered vent site on the Indian Ridge, where megafauna biomass is dominated by shrimp swarms of the genus Rimicaris, was also reported to have an end-member fluid iron-

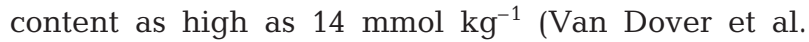
2001). This is lower that at Rainbow but much higher than this is generally the case at MAR sites (Von Damm 1995, Douville et al. 2001). Abundant iron-oxide microbial mats were reported for the new Indian Ridge site, suggesting that microbial iron-oxidation may be an important chemoautotrophic process there (Emerson \& Moyer 2002). Nothing is known about the shrimp epibionts or associated minerals at the new site, but the occurrence of iron-oxidising epibionts could be postulated in this case also .

\section{Conclusions}

The distribution of bacteria and mineral deposits in the branchial chamber of the shrimp defines 3 compartments, which differ in bacterial and mineral abundance, and in the nature of the minerals. These 3 com- partments are functionally different. They represent distinct microenvironments, probably providing different chemical conditions, which may promote different bacterial metabolisms. We propose that the epibiotic bacteria of the antero-dorsal part of the branchial chamber relies on iron-oxidation for growth. If this is true, this symbiosis would appear unique, as most previously studied symbioses at deep-sea vents rely on sulphide or methane oxidation. Further microbiological investigations are required to confirm this hypothesis, and to determine if this bacteria-Rimicaris exoculata association is widespread or specific to the peculiar chemical environment of the Rainbow vent field.

Acknowledgements. The authors want to thank P. M. Sarradin, chief scientist of the ATOS cruise, as well as the captain and crew of the RV 'Atalante', the ROV 'Victor' team, and P. Rodier for technical assistance. The authors wish also to express their appreciation to N. Decloux (microtomy and SEM preparation) for her excellent technical assistance. We also thank the 4 reviewers for providing constructive comments for rewriting this paper. This work was partly funded with the help of the Dorsales Programm (INSU, CNRS SDV, Ifremer), the VENTOX program (EVK3 CT-1999-0003) and the Geomex program (CNRS). A fellowship for M.Z. and part of this work were supported by the Belgian Fund for Joint Basic Research (F.R.F.C Belgium, convention no. 2.4533.01.F).

\section{LITERATURE CITED}

Allen DE, Seyfried WE (2003) Compositional controls on vent fluids from ultramafic-hosted hydrothermal systems at mid-ocean ridges: an experimental study at $400^{\circ} \mathrm{C}, 500$ bars. Geochim Cosmochim Acta 67:1531-1542

Batang ZB, Suzuki H (1999) Gill-cleaning mechanisms of the mud-lobster Thalassina anomalia (Decapoda: Thalassinidea: Thalassinidae). J Crustac Biol 19:671-683

Buffle J, De Vitre R (1994) Chemical and biological regulation of aquatic systems. Lewis Publishers, Boca Raton, FL

Casanova B, Brunet M, Segonzac M (1993) L'impact d'une épibiose bactérienne sur la morphologie fonctionnelle de crevettes associées à l'hydrothermalisme médio-Atlantique. Cah Biol Mar 34:573-588

Charlou JL, Donval JP, Fouquet Y, Jean-Baptiste P, Holm N, Caccavo FJ (2002) Geochemistry of high $\mathrm{H}_{2}$ and $\mathrm{CH}_{4}$ vent fluids issuing from ultramafic rocks at the Rainbow hydrothermal field ( $36^{\circ} 14^{\prime}$ N, MAR). Chem Geol 191:345-359

Coale KH, Chin CS, Massoth GJ, Johnson KS, Baker ET (1991) In situ chemical mapping of dissolved iron and manganese in hydrothermal plumes. Nature 352:325-328

Compère P, Jeuniaux C, Goffinet G (2004) Chapter 3, The integument: morphology and biochemistry. In: Forest J, von Vaupel Klein JC (eds) Treatise on zoology 1. Anatomy, taxonomy, biology. Vol Crustacea. Koninklijke Brill, Leiden, p 1-85

Douville E, Charlou JL, Oelkers EH, Bienvenu P and 5 others (2002) The rainbow vent fluids $\left(36^{\circ} 14^{\prime} \mathrm{N}, \mathrm{MAR}\right)$ : the influence of ultramafic rocks and phase separation on trace metal content in Mid-Atlantic Ridge hydrothermal fluids. Chem Geol 184:37-48

Drach P, Tchernigovtzeff C (1967) Sur la méthode de détermi- 
nation des stades d'intermue et son application générale aux Crustacés. Vie Milieu 18A:595-609

Edwards KJ, McCollom TM, Konishi H, Buseck PR (2003) Seafloor bioalteration of sulphide minerals: results from in situ incubations studies. Geochim Cosmochim Acta 67: 2843-2856

Emerson D, Moyer CL (1997) Isolation and characterization of novel iron-oxidizing bacteria that grow at circumneutral pH. Appl Environ Microbiol 63:4784-4792

Emerson D, Moyer CL (2002) Neutrophilic Fe-oxidizing bacteria are abundant at the Loihi seamount hydrothermal vents and play a major role in Fe oxide deposition. Appl Environ Microbiol 68(6):3085-3093

Ferris FG, Hallberg RO, Lyven B, Pedersen K (2000) Retention of strontium, cesium, lead and uranium by bacterial iron oxides from a subterranean environment. Appl Geochem 15:1035-1042

Fortin D, Ferris FG, Scott SD (1998) Formation of Fe-silicates and Fe-oxides on bacterial surfaces in samples collected near hydrothermal vents on the southern Explorer Ridge in the northeast Pacific Ocean. Am Mineralogist 83: 1399-1408

Gebruk AV, Pimenov NV, Savvichev AS (1993) Feeding specialization of bresiliid shrimps in the TAG site hydrothermal community. Mar Ecol Prog Ser 98:247-253

Gebruk AV, Southward EC, Kennedy H, Southward AJ (2000) Food sources, behaviour, and distribution of hydrothermal vent shrimp at the Mid-Atlantic Ridge. J Mar Biol Assoc UK 80:485-499

Gloter A, Zbinden M, Guyot F, Gaill F, Colliex C (2004) Formation and stabilization of mixed valence ferrihydrite on bacterial surfaces from hydrothermal vents. Earth Planet Sci Lett 222:947-957

James RH, Elderfield H (1996) Dissolved and particulate trace metals in hydrothermal plumes at the Mid-Atlantic Ridge. Geophys Res Lett 23:3499-3502

Johnson KS, Childress J, Hessler RR, Sakamoto-Arnold C (1988) Chemical and biological interactions in the Rose Garden hydrothermal vent field. Deep-Sea Res Part A 35: $1723-1744$

Juniper SK, Tebo BM (1995) Microbe-metal interactions and mineral deposition at hydrothermal vents. In: Karl D (ed) The microbiology of deep-sea hydrothermal vents. CRC Press, Boca Raton, FL, p 219-253

Juniper SK, Martineu P, Sarrazin J, Gelinas Y (1995) Microbial mineral floc associated with nascent hydrothermal activity on Coaxial segment, Juan de Fuca Ridge. Geophys Res Lett 22:179-182

Kennedy CB, Scott SD, Ferris FG (2003) Ultrasutructure and potential sub-seaflor evidence of bacteriogenic iron oxide from Axial Volcano, Juan de Fuca Ridge, north-east Pacific Ocean. FEMS Microbiol Ecol 43:247-254

King DW (1998) Role of carbonate speciation on the oxidation rate of Fe(II) in aquatic systems. Environ Sci Technol 32: 2997-3003

Konhauser KO (1998) Diversity of bacterial iron mineralization. Earth-Sci Rev 43:91-121

Lau WW, Jumars PA, Armbrust EV (2002) Genetic diversity of attached bacteria in the hindgut of the deposit-feeding shrimp Neotrypaea (formerly Callianassa) californiensis (Decapoda: Thalassinidae). Microb Ecol 43:455-466

Le Bris N, Sarradin PM, Birot D, Alayse AM (2000) A new chemical analyser for in situ measurement of nitrate and total sulphide over hydrothermal vent biological communities. Mar Chem 72:1-15

Le Bris N, Sarradin PM, Pennec S (2001) A new deep-sea probe for in situ $\mathrm{pH}$ measurement in the environment of hydrothermal vent biological communities. Deep-Sea Res Part I 48:1941-1951

Lechaire JP, Shillito B, Frébourg G, Gaill F (2002) Elemental characterization of microorganism granules by EFTEM in the tube wall of a deep-sea vent invertebrate. Biol Cell 94: $243-249$

Luther GW, Rozan TF, Taillefert M, Nuzzio DB, Meo CD, Shank TM, Lutz RA, Cary SC (2001) Chemical speciation drives hydrothermal vent ecology. Nature 410:813-816

Martinez AS (2001) Adaptations morphofonctionnelles des crustacés caridés et brachyoures. La salinité du milieu hydrothermal profond. PhD thesis, University of Montpellier II

Millero FJ, Sotolongo S, Izaguirre M (1987) The oxidation kinetics of $\mathrm{Fe}(\mathrm{II})$ in seawater. Geochim Cosmochim Acta 51:793-801

Nelson DC, Fischer CR (1995) Chemoautotrophic and methanotrophic endosymbiotic bacteria at deep-sea vents and seeps. In: Karl D (ed) The microbiology of deep-sea hydrothermal vents. CRC Press, Boca Raton, FL, p 125-166

Neubauer SC, Emerson D, Megonigal JP (2002) Life at the energetic edge: kinetics of circumneutral iron oxidation by lithotrophic iron-oxidizing bacteria isolated from the wetland-plant rhizosphere. Appl Environ Microbiol 68(8): 3988-3995

Polz MF, Cavanaugh CM (1995) Dominance of one bacterial phylotype at a Mid-Atlantic Ridge hydrothermal vent site. Proc Natl Acad Sci USA 92:7232-7236

Polz MF, Robinson JJ, Cavanaugh CM, Van Dover CL (1998) Trophic ecology of massive shrimp aggregations at a midAtlantic Ridge hydrothermal vent site. Limnol Oceanogr 43:1631-1638

Pond DW, Dixon DR, Bell MV, Fallick AE, Sargent JR (1997) Occurrence of 16:2(n-4) and 18:2(n-4) fatty acids in the lipids of the hydrothermal vent shrimps Rimicaris exoculata and Alvinocaris markensis: nutritional and trophic implications. Mar Ecol Prog Ser 156:167-174

Rawlings DE, Kusano T (1994) Molecular genetics of Thiobacillus ferrooxidans. Microbiol Rev 58:39-55

Rieley G, Van Dover CL, Hedrick DB, Eglinton G (1999) Trophic ecology of Rimicaris exoculata: a combined lipid abundance/stable isotope approach. Mar Biol 133:495-499

Sarradin PM, Caprais JC, Briand P, Gaill F, Shillito B, Desbruyères $D$ (1998) Chemical and thermal description of the environment of the Genesis hydrothermal vent community $\left(13^{\circ} \mathrm{N}, \mathrm{EPR}\right)$. Cah Biol Mar 39:159-167

Segonzac M (1992) Les peuplements associés à l'hydrothermalisme océanique du Snake Pit (dorsale médioAtlantique, $23^{\circ} \mathrm{N}, 3480 \mathrm{~m}$ ): composition et microdistribution de la mégafaune. CR Acad Sci Sér III 314:593-600

Segonzac M, de Saint-Laurent M, Casanova B (1993) L'énigme du comportement trophique des crevettes Alvinocarididae des sites hydrothermaux de la dorsale médio-atlantique. Cah Biol Mar 34:535-571

Shillito B, Jollivet D, Sarradin PM, Rodier P, Lallier F, Desbruyères D, Gaill F (2001) Temperature resistance of Hesiolyra bergi, a polychaetous annelid living on vent smoker walls. Mar Ecol Prog Ser 216:141-149

Straub KL, Benz M, Schinck B (2001) Iron metabolism in anoxic environments at near neutral pH. FEMS Microbiol Ecol 34:181-186

Suzuki H, McLay CL (1998) Gill-cleaning mechanisms of Paratya curvirostris (Caridea: Atyidae) and comparison with seven species of Japanese atyid shrimps. J Crustac Biol 18:253-270

Van Dover CL, Fry B, Grassle JF, Humphris SE, Rona PA (1988) Feeding biology of the shrimp Rimicaris exoculata 
at hydrothermal vents on the Mid-Atlantic Ridge. Mar Biol 98:209-216

Van Dover CL, Humphris SE, Fornari D, Cavanaugh CM and 23 others (2001) Biogeography and ecological setting of Indian Ocean hydrothermal vents. Science 294:818-823

Vernet G, Charmentier-Daures M (1994) Mue, autotomie et régénération. In: Forest $\mathrm{J}$ (ed) Traité de zoologie 7 , Crustacés (1), Morphologie, physiologie, reproduction, embryologie. Masson, Paris, p 107-194

Von Damm KL (1995) Controls on the chemistry and temporal variability of seafloor hydrothermal fluids. In: Humphris S, Zierenberg R, Mullineaux L, Thomson R (eds) Seafloor hydrothermal systems. Physical, chemical, biological and geological interactions. American Geophysical Union, Washington, p 222-247

Williams AB, Rona PA (1986) Two new caridean shrimps (Bre-

Editorial responsibility: Otto Kinne (Editor),

Oldendorf/Luhe, Germany siliidae) from a hydrothermal field on the Mid-Atlantic Ridge. J Crustac Biol 6:446-462

Wirsen CO, Jannasch HW, Molyneaux SJ (1993) Chemosynthetic microbial activity at Mid-Atlantic Ridge hydrothermal vent sites. J Geophys Res B 98:9693-9703

Zbinden M, Cambon-Bonavita MA (2003) Occurrence of Deferribacterales and Entomoplasmatales in the deep-sea shrimp Rimicaris exoculata gut. FEMS Microbiol Ecol 46: 23-30

Zbinden M, Martinez I, Guyot F, Cambon-Bonavita MA, Gaill F (2001) Zinc-iron sulphide mineralization in tubes of hydrothermal vent worms. Eur J Mineral 13:653-658

Zbinden M, Le Bris N, Compère P, Martinez I, Guyot F, Gaill F (2003) Mineralogical gradients associated with alvinellids at deep-sea hydrothermal vents. Deep-Sea Res Part I 50:269-280

Submitted: January 26, 2004; Accepted: July 8, 2004

Proofs received from author(s): December 7, 2004 